University of Nebraska - Lincoln

DigitalCommons@University of Nebraska - Lincoln

1993

\title{
Reflectance Models for Quantifying Chlorophyll in Inland Waters
}

Anatoly A. Gitelson

University of Nebraska - Lincoln, agitelson2@unl.edu

Follow this and additional works at: https://digitalcommons.unl.edu/natrespapers

Part of the Natural Resources and Conservation Commons

Gitelson, Anatoly A., "Reflectance Models for Quantifying Chlorophyll in Inland Waters" (1993). Papers in Natural Resources. 233.

https://digitalcommons.unl.edu/natrespapers/233

This Article is brought to you for free and open access by the Natural Resources, School of at DigitalCommons@University of Nebraska - Lincoln. It has been accepted for inclusion in Papers in Natural Resources by an authorized administrator of DigitalCommons@University of Nebraska - Lincoln. 
Published in: Geoscience and Remote Sensing Symposium, 1993. IGARSS '93. Better Understanding of Earth Environment DOI: 10.1109/IGARSS.1993.322373. Copyright 1993, IEEE. Pages 1,944-1,946, volume 4

REFLECTANCE MODELS FOR QUANTIFYING CHLOROPHYLL IN INLAND WATERB

Anatoly Gitelson

J. Blaustein Institute for Desert Research, Ben-Gurion University of the Negev, Sede-Boker Campus 84990, Israel

\section{ABSTRACT}

To develop the models for chlorophyll (CHL) estimation, the nature of a peak near $700 \mathrm{~nm}$ on the reflectance spectrum of water should be investigated. simultaneous measurements of the reflectance spectra from 400 to $750 \mathrm{~nm}$ and relevant water quality constituent concentrations were carried out. A shift of the peak position and an increase of the peak magnitude, when chlorophyll concentration increased, were observed. The relationships of the magnitude and position of the peak to chlorophyll-a, were applied to several independent data sets. The parameters of the peak can be used as precise indicators of CHL content in inland waters.

Key words: radiance, algorithm.

\section{INTRODUCTION}

The red region of the reflectance spectrum is very important for the remote sensing of inland and coastal waters. This is due to several spectral features unique to $\mathrm{CHL}$ that appear in this region. A strong peak at about $685 \mathrm{~nm}$ in the upwelling radiance spectrum in natural waters was observed by Neville and Gower [1] There have been several attempts to explain this peak [1-5], but to date, it is not clear how its position and magnitude depend on $\mathrm{CHL}$ concentration.

The purpose of this paper is to present data on characteristic features of the reflectance spectrum between 680 and 720 $\mathrm{nm}$ and to contribute to the understanding of the nature of the peak. Having found the relationships between peak parameters and relevant constituent concentrations, they can be used to develop algorithms for the comprehensive remote sensing of water quality.

\section{METHODS}

Several thousand spectral irradiance measurements, along with simultaneous ground-data references, were taken in various water bodies $[6,8]$. In the study of the ecosystems, CHL ranged from 0.1 to $350 \mu \mathrm{g} / \mathrm{l}$, the suspended matter ranged from 0.1 to $66 \mathrm{mg} / 1$, and absorption coefficient of dissolved organic matter at the wavelength $380 \mathrm{~nm}$ varied from 0.1 to $12 \mathrm{~m}^{-1}$.

A radiometer, recording from 400 to 750 $\mathrm{nm}$, with a spectral resolution of about 1 $\mathrm{nm}$ and total field of view of $7^{\circ}$, was used to measure the upwelling radiance and downweliing irradiance. Immediately after sampling, the fluorescence spectrum of each sample was measured using a Neva fluorimeter in the range of 640 to $750 \mathrm{~nm}$ with a spectral resolution of more than $0.7 \mathrm{~nm}$.

The reflectance in the region of 450 to $750 \mathrm{~nm}$ was calculated for various concentrations of relevant constituents $[2,7]$. For the emission peak of chlorophyll at $680 \mathrm{~nm}$ a Gaussian distribution was assumed [2].

\section{RESULTS AND DISCUSBION}

The peak height was quantified by measuring the difference between reflectance at the wavelength where the maximum reflectance was observed, and the base 1 ine, interpolated from measurements at 670 and $730 \mathrm{~nm}[8]$. Another way to quantify the peak height ( $R_{\text {maxred }}$ ) was by normalizing it to the reflectance at 560 $\mathrm{nm}(\mathrm{R}(560))$. The ratio of $R_{\text {maxred }} \mathrm{R}(560)$ versus the chlorophyll-a concentration for the first data set (the Don river 1983) was described by a function

Rmaxred $/ R(560)=0.226 \mathrm{Cchl} 0.362$

with a coefficient of determination $\left(\mathrm{r}^{2}\right)$ of more than 0.93 . Then the regression was applied to independent data sets (Table 1).

The increase in the peak height was accompanied by a shift in the position towards the longer wavelengths; meanwhile, the peak of the $\mathrm{CHI}$ fluorescence had a permanent position at $680 \mathrm{~nm}$ for all the samples measured. The $680 \mathrm{~nm}$ for all the sur near $3 \mathrm{ug} / \mathrm{l}$ was observed at 685 ; it shifted to a longer wavelength reaching $715 \mathrm{~nm}$ for CHL at more than $100 \mathrm{ug} / \mathrm{l}$. For the first data set the relationship peak position versus $C_{\mathrm{chl}}$ was obtained in the form: 
Published in: Geoscience and Remote Sensing Symposium, 1993. IGARSS '93. Better Understanding of Earth Environment DOI: 10.1109/IGARSS.1993.322373. Copyright 1993, IEEE. Pages 1,944-1,946, volume 4

Table 1. Comparison of estimated ( $\mathrm{C}_{\text {est }}$ ), using equation (1), and measured ( $C_{\text {meas }}$ ) chlorophyll-a concentration. a and $b$ are parameters of the equation $C_{e s t}=a+b * C_{\text {meas. }}$. Std Err is a standard error of chlorophyll estimation in $\mu \mathrm{g} / 1$. $r$ is correlation coefficient.

\begin{tabular}{llllll}
\hline Water body & & $\mathrm{a}$ & $\mathrm{b}$ & $\mathrm{r}^{2}$ & std Err \\
\hline & & & & & \\
\hline Northern Donec & 1983 & 2.06 & 0.768 & 0.88 & 1.51 \\
Don river & 1984 & 0.33 & 0.912 & 0.95 & 1.61 \\
Northern Donec & 1984 & 1.73 & 0.855 & 0.91 & 1.85 \\
Lake Balaton & 1985 & 2.15 & 0.754 & 0.87 & 2.40 \\
Lake Balaton & 1986 & 0.85 & 0.903 & 0.83 & 2.70 \\
\hline
\end{tabular}

Peak position $=682.14+0.322 * \mathrm{C}_{\mathrm{chl}}, \mathrm{nm}(2)$

with $r^{2}=0.95$ and estimation error of the peak position less than $0.93 \mathrm{~nm}$. Then Eq. 2 was applied to several independent data sets. Calculated and retrieved (from derivative of reflectance spectra) values of the peak position were compared (Table 2). The parameter "a" remained almost constant for these water bodies.

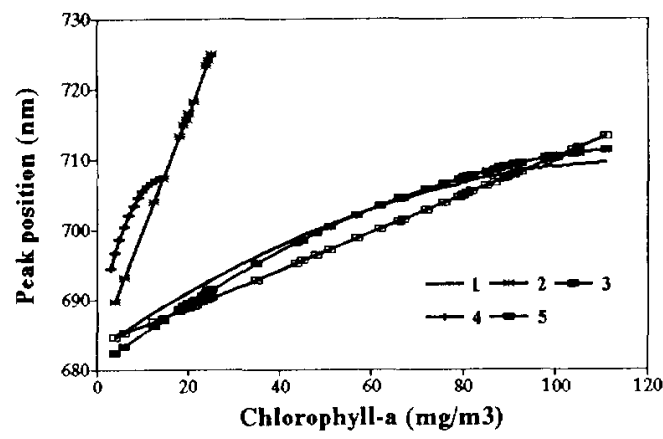

Figure 1. The peak position plotted versus CHL concentration. Comparison the results of calculations and measurements. Calculations: 1- Kishino et al. [9] for quantum fluorescence efficiency 2.5\%; 2Vasilkov and Kopelevich [4]; CHL fluorescence was not taken into consideration; 3 - present work for quantum fluorescence efficiency $2.5 \%$. Measurements: 4- Vos et al. [5]; 5present work; the line presents eq. (2).
The measured values of the peak position were compared with various model calculations (Fig. 1 and rable 3 ). The calculation [9] (curve 1 ) is very close to our calculation and experimental results. BY contrast, measurements [5] (curve 4) and the calculations [4] (curve 2) both show a sharp shift in the peak position when $\mathrm{CHL}$ concentration increases. The slopes of these relationships are three times steeper than the calculations [9] (curve 1), our calculations (curve 3) and measurements (curve 5).

A difference between the present results and those [5] may have many causes. Insitu phytoplankton fluorescence is influenced not only by the chlorophyll concentration, but also by the spectral distribution of the incident light, turbidity of water, phytoplankton species and phytoplankton state. A difference in these factors under artificial [5] and natural conditions can be very significant.

\section{CONCLU8IONS}

The following conclusions can be drawn for the conditions of this study :

1. The magnitude of the peak near $700 \mathrm{~nm}$ on the radiance spectrum correlates strongly with the chlorophyll concentration. The ratio $R_{\text {maxred }} / \mathrm{R}(560)$

Table 2. Parameters of the relationships peak position = $a+b * C_{c h l} ; b$ is standard deviation of $b$. a and std Err of the peak position in $\mathrm{nm}$.

\begin{tabular}{lcccccc}
\hline \multicolumn{1}{c}{ Water bodies } & $\mathrm{a}$ & $\mathrm{b}$ & $\mathrm{b}$ & $\mathrm{r}^{2}$ & std Err \\
\hline Northern Donec & 1984 & 0.956 & 682.14 & 0.322 & 0.022 & 0.93 \\
$\begin{array}{l}\text { Don river } \\
\text { Lake Balaton }\end{array}$ & 1984 & 0.785 & 683.73 & 0.257 & 0.032 & 1.68 \\
$\begin{array}{l}\text { All water bodies } \\
\text { together }\end{array}$ & 0.921 & 683.67 & 0.265 & 0.010 & 2.80 \\
\hline
\end{tabular}


Published in: Geoscience and Remote Sensing Symposium, 1993. IGARSS '93. Better Understanding of Earth Environment DOI: 10.1109/IGARSS.1993.322373. Copyright 1993, IEEE. Pages 1,944-1,946, volume 4

\begin{tabular}{|c|c|c|c|c|}
\hline Authors & a & $\mathrm{b}$ & $\mathrm{d}$ & Notes \\
\hline 1. Kishino et al, 1986 & 683.0 & 0.44 & -0.018 & $\mathrm{a}(380)=0, \mathrm{c}_{\mathrm{sm}}=0$ \\
\hline 2. Vasilkov and Kopelevich, & 683.0 & 1.68 & 0 & $a(380)=1.0 \mathrm{~m}^{-1}$ \\
\hline $\begin{array}{l}\text { 3. Present study } \\
\text { calculation }\end{array}$ & 680.4 & 0.49 & -0.019 & $\begin{array}{l}\mathrm{C}_{\mathrm{sm}}=5 \mathrm{mg} / 1 \\
\mathrm{a}(380)=3 \mathrm{~m}^{-1}\end{array}$ \\
\hline 4. Vos et al., 1986 & 686.9 & 2.86 & -0.084 & $\begin{array}{l}\mathrm{C}_{\text {Chl }}=3-13.5 \mathrm{ug} / 1 \\
\mathrm{a}(3 \mathrm{~B} 0)=5-12 \mathrm{~m}\end{array}$ \\
\hline $\begin{array}{l}\text { 5. Present study } \\
\text { measurements }\end{array}$ & 683.5 & 0.27 & 0 & $\begin{array}{l}a(380)=2-12 \mathrm{~m}^{-1} \\
\mathrm{c}_{\mathrm{sm}}=4-66 \mathrm{mg} / 1\end{array}$ \\
\hline
\end{tabular}

can predict CHL concentration for water bodies of different trophic states and allows the assessment of the CHL with an estimation error of less than $3 \mathrm{ug} / 1$.

2. The position of the peak near $700 \mathrm{~nm}$ is very closely related to $\mathrm{CHL}$ concentration. For all the water bodies studied, a linear regression with $r^{2}$ more than 0.9 for this relationship and with an estimation error of less than $2.5 \mathrm{~nm}$ was obtained.

3. CHL fluorescence is the only cause of the peak for chlorophyll-a concentration up to $10 \mathrm{ug} / 1$. For CHL reaching 15-20 ug/l, the parameters of the peak are caused by both CHL absorption and fluorescence. For CHL concentration above $30 \mathrm{ug} / 1$, the absorption of CHL plays a dominant role in the formation of the peak.

4. The relationships of the magnitude and the peak position on the radiance spectrum to chlorophyll concentration can be used as precise indicators and predictors for the phytoplankton content in productive inland waters.

\section{REFERENCES}

1. R.A. Neville and J.F.R. Gower, "Passive remote sensing of phytoplankton via chlorophyll-a fluorescence", J . Geoph. Res., vol. 82, pp. 3487-3493, 1977 .

2. H.R. Gordon, "Diffusive reflectance of the ocean: the theory of its augmentation by chlorophyll-a fluorescence at $685 \mathrm{~nm}$ ", Appl. Opt., vol. 18, pp. 1161-1166, 1979 .

3. A. Morel and L. Prieur, "Analysis of variation in ocean color" Limn. \& ocean., vol. 22, pp. 709-722, 1977.

4. A. Vasilkov and o. Kopelevich, "The reasons of maximum at about 700 ' $\mathrm{nm}$ on radiance spectra of the sea", oceanology, vol. 22, pp. 945-950, 1982 .
5. W.L. Vos, M. Donze, and H. Bueteveld, "On the reflectance spectrum of algae in water: The nature of the peak at $700 \mathrm{~nm}$ and its shift with varying concentration", Comm. on San. Eng. and Water Management, Delft, The Netherlands, Tech. Rep. 86-22, 1986.

6. A. Gitelson, "Aerospace Remote Sensing Monitoring of Inland water quality", Earth and Atmospheric Remote Sensing, Proc. SPIE 1492, 1991, pp. 665-677.

7. A. Vasilkov and A. Gitelson, "Spectral dependence of the light scattering characteristics of absorbing organic hydrosol", Izvestiya, Atmosph. and ocean. Physics, vol. 24, pp. 968-972, 1988.

8. A. Gitelson, "The peak near $700 \mathrm{~nm}$ on radiance spectra of algae and water: relationships of its magnitude and position with chlorophyll concentration", Int. J. Remote Sensing, vol. 13, pp. $3367-3373,1992$.

9. M. Kishino, S. Sugihara, and N. Okami, "Theoretical analysis of the in-situ fluorescence of chlorophyll-a on the underwater spectral irradiance", Bull. de la Soc. Franco-Japonaise d'Oceanographie, vol. 24, pp. 130-138, 1986. 